
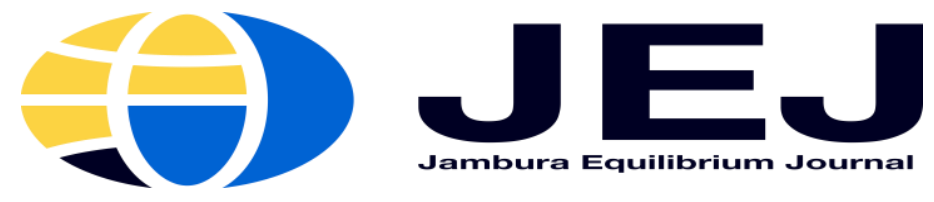

Volume 1. Issue 1. January 2019

P-ISSN 2655-9110

http://ejurnal.ung.ac.id/index.php/equij

\title{
Effects of Capital Expenditures, Development Index and Unemployment on Poverty in Gorontalo Province
}

\author{
Dewi Purnama Isa ${ }^{1}$, Muhammad Amir Arham ${ }^{2}$, Sri Indriyani S. Dai ${ }^{3}$ \\ Faculty of Economics, Gorontalo State University \\ Faculty of Economics, Gorontalo State University \\ Faculty of Economics, Gorontalo State University
}

\begin{abstract}
This study aims to analyze the effect of capital expenditure in the form of regional government budgets to obtain fixed assets, the Human Development Index and Unemployment to the Poverty Level in Gorontalo Province. The data used are secondary data obtained from the Gorontalo Province Central Bureau of Statistics and the Registration Management Information System (Simreg Bappenas) during the period 2010-2015, the unit of analysis is 5 districts 1 city in Gorontalo Province. The research estimate uses panel data multiple regression analysis with the Fixed Model Effect (FEM) method. The results of the study indicate that ( $i$ ) The amount of capital expenditure allocated by each region in Gorontalo Province shows a positive and significant influence on the Poverty Level in the 2010-2016 period. (ii) The Human Development Index, which is a benchmark for the achievement of an area in three basic things such as life expectancy, education level, and a decent level of life, turned out to have a positive and significant influence on the District / City Kemskinan Level in Gorontalo Province. (iii) Unemployment has a positive but not significant effect on the District / City Poverty Level in Gorontalo Province in the period 2010-2016.
\end{abstract}

\section{Keywords: Capital Expenditures, Development Index, Unemployment, Poverty}

Poverty is a problem faced by all countries in the world, especially developing countries, such as Indonesia. The problem of poverty is still the subject matter that must get extra attention. In the current conditions, the level of poverty is not only viewed from the low quality of the economy, but has been viewed from different angles and depends on the views used, the poverty limit has also shifted.
According to the World Bank (in Whisnu Adhi Saputra, 2011), one of the causes of poverty is due to lack of income and assets to meet basic needs such as food, clothing, housing and acceptable health and education levels (acceptable) .

The strategic problems in Gorontalo Province are not much different from the problems at the national level, namely the problem of poverty which is still relatively 
high, because it is the responsibility of the government, both local and central government, as a buffer in the process of improving the lives of the poor. The government has the responsibility of finding a way out and formulating measures to overcome poverty.

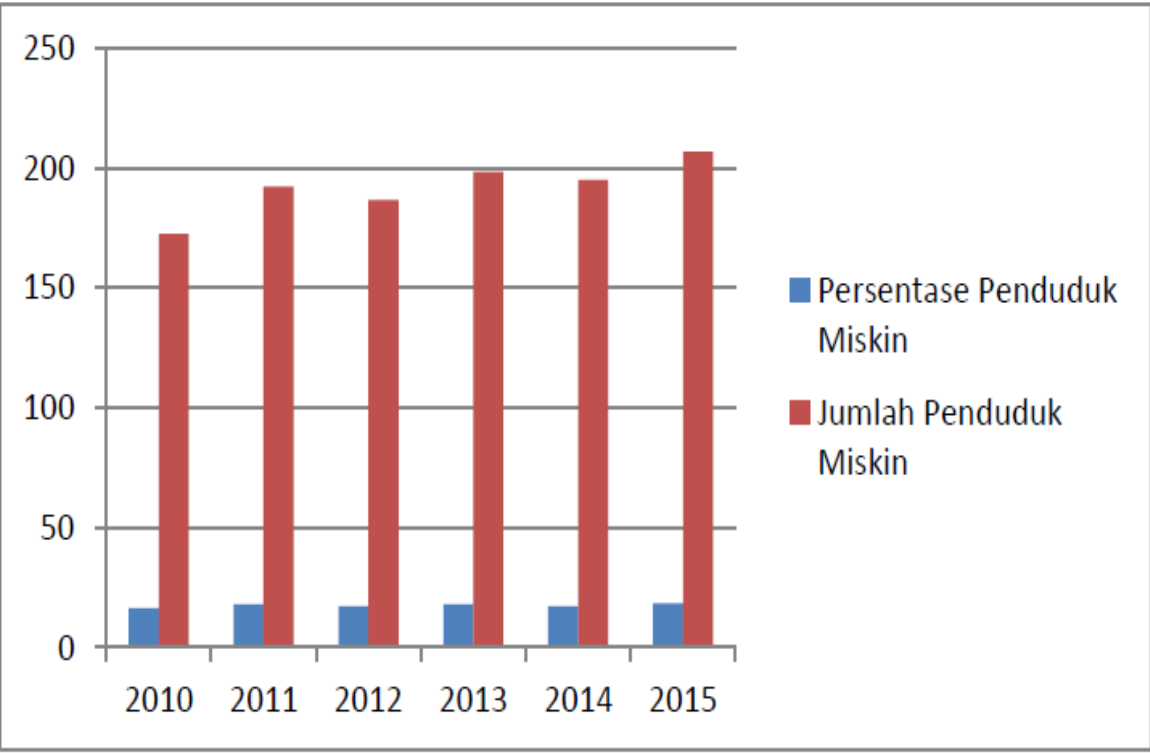

Figure 1. Percentage (\%) and Number of Poor (Thousands) in Gorontalo

Province in 2010-2015 (Source: Central Bureau of Statistics of Gorontalo Province,

\section{METHODS}

The data used in this study is secondary data obtained from the Gorontalo Provincial Statistics Agency and the Registration Management Information System (Simreg Bappenas) during the period 2010-2015. The data studied include capital expenditure, human development index, unemployment and poverty. The type of data used is panel data which is a combination of cross section and time series. The cross section data is 5 districts and 1 city in Gorontalo Province, while the time series for the period 2010-2015.

\section{RESULTS}

\section{Regression Analysis Results}

Because the data analyzed is in the form of pooled data (a combination of cross section data / area with time series data / year), the regression analysis used is panel data regression. In the poverty model of districts / cities in Gorontalo Province allegedly influenced by Capital 
Expenditures, Human Development Index and Unemployment. Because the data used from the research is panel data (pool of data), where it is very possible to occur interference between time (time series), between individuals (cross section) or both. In connection with this matter, it is necessary to do a test to determine the right method according to the characteristics of panel data. Is the disorder fixed (fixed) or random (random). To determine these criteria, testing was carried out using the Hausman Spesification Test. If based on the test stating that the interference between individuals (cross section) is fixed then the Fixed Effect Model (FEM) method is used and if it is random, it is more appropriate to use the Random Effect Model (REM) method. The results of the Hausman Spesification Test in poverty equations are as follows:

Table 1. Hausman Specification Test

\begin{tabular}{lrrr} 
Test Summary & $\begin{array}{c}\text { Chi-Sq. } \\
\text { Statistic }\end{array}$ & Chi-Sq. d.f. & Prob. \\
\hline \hline Cross-section random & 48.317967 & 3 & 0.0000 \\
\hline \hline
\end{tabular}

Source: Processing Results (Eviews9), 2018

The results of panel data regression analysis are as follows:

Table 2. Regression Estimation Results

\begin{tabular}{lrrrr}
\hline \multicolumn{1}{c}{ Variable } & Coefficien & & & \\
& $\mathrm{t}$ & Std. Error & $\mathrm{t}$-Statistic & Prob. \\
\hline \hline C & 1.155553 & 5.498240 & 0.210168 & 0.8351 \\
LOG(BM?) & 0.595542 & 0.380393 & $1.565594^{*}$ & 0.1291 \\
IPM? & 0.149304 & 0.083737 & $1.783018^{* *}$ & 0.0858 \\
Unmployment & 0.045499 & 0.063514 & -0.716370 & 0.4799 \\
\hline \hline R-squared & 0.996295 & Durbin-Watson stat & 2.607656 \\
Adjusted R-squared & 0.995197 & & & \\
F-statistic & 907.4621 & & & \\
\hline \hline
\end{tabular}

Dependent Variable: Poverty

The estimation results of the regression model using E-Views are as follows:

$$
\begin{aligned}
& Y_{\text {it }}=1,155+0,595 \log (B M)+ \\
& 0,149(\text { IPM })+0,045(\text { Unemp })+\varepsilon
\end{aligned}
$$

The interpretation of the results of the regression analysis above are as follows:

1. Without being influenced by any variable, poverty will be worth 1,155 
percent (ceteris paribus) during 20102015.

2. Capital Expenditure has a positive and significant effect on poverty. Every increase in the value of capital expenditure of one billion will increase poverty by 0.595 percent.

3. The Human Development Index (HDI) has a positive and significant influence on poverty. Each increase in the HDI value by one percent will increase poverty by 0.149 percent.

4. Unemployment has a positive but not significant effect on poverty in districts / cities in Gorontalo Province. The one percent increase in the unemployment rate will increase poverty by 0.045 percent.

\section{DISCUSSION}

Estimation results of regression of poverty equation show that the value of the elasticity coefficient for the government expenditure variable for capital expenditure is 0.595 , which means that every increase in the ratio of government expenditure to capital expenditure to total development expenditure by one percent will be responded to by an increase in poverty of 0.595 percent. However, the effect is not significant at 90 percent confidence level.
This finding shows that, although the amount of the budget for capital expenditure is gradually increasing, it has not been able to provide a significant influence to reduce the amount of poverty. One of the results is strongly related to the still low composition of capital expenditure allocated for development expenditure compared to the real need to accommodate all needs in realizing better quality of society, including in providing more equitable benefits by making poor people a priority. Seeing the amount of capital expenditure realized in each district / city is also still relatively small, capital expenditure budgeted by the district / city government is not able to reduce poverty in districts / cities in Gorontalo Province. This finding is in line with the research conducted by Omari and Muturi (2016) which suggested that capital expenditure in agriculture and health had a positive effect on poverty levels in Kenya. Besides that, it also supports the results of a study conducted in Iran by Dahmardeh and Tabar (2013) which suggested that capital expenditure in the construction sector had a positive effect on poverty in two provinces in Iran. The research that also supports the results of this estimation is a study conducted by Lavenia Kotambunan, 
Sutomo Wim Palar and Richard L. Tumikar (2016) who suggested a positive result of the effect of capital expenditure on poverty.

The regression estimation results of the poverty equation show that changes in the human development index as a proxy of human capital have a positive and significant effect on changes in the amount of poverty, with an elasticity coefficient of 0.149 which means that each increase in human capital by one percent will increase the amount of poverty by 0.149 percent. This certainly makes sense because through lower levels of education and poor health conditions will usually reduce human capacity to share in economic growth.

When people who are able to get a higher level of education and better health conditions, tend to have higher productivity and certainly will affect the increase in income which in turn will reduce poverty. What happened in the Regency / City in Gorontalo Province, the Human Development Index value, especially for five districts, only ranged from 59 to 67 while for Gorontalo City the highest was from all districts whose HDI values reached 73-75 from 2010 to 2015 . These results are in line with the findings conducted by Aisyah (2004) who suggested that the relationship of economic development and indicators of HDI in 1996 and 1999 all had a positive and significant relationship at the level of 10 percent. While the relationship of economic development in 2001 and 2002 HDI indicators have a positive but not significant relationship. In addition, the results of a study conducted by Sudarlan (2015) which stated in his research that the human development index seen from the education and health sectors had a positive influence on the percentage of poor people, depth index of poverty and severity of poverty, but from health only had a positive effect on the index severity of poverty.

Poverty is a complicated problem. Improvements in economic indicators do not necessarily indicate an increase in people's welfare. In other words, poverty must be dealt with thoroughly and not enough to only be done in terms of economic development, human development is thought to be very important in reducing poverty. This is because education and good health enable the poor to increase the value of their assets (Lanjouw, Pradhan, Saadah, Sayed, and Sparrow, 2001 in Brata, 2005) Estimation results of regression of poverty equation show that changes in the number of unemployed have a positive and significant effect on changes in the amount poverty. 
With an elasticity coefficient of 0.047 which means that each increase in the amount of collateral by 1 percent will increase the number of poverty by 0.047 percent. This finding indicates a close relationship between the increase in the number of unemployed and the high number of poverty. On the other hand, this indicates that regularly received wages and salaries are the main source of income for some poor people so that the incidence of unemployment will cause the loss of a large portion of the income used for consumption. Implicitly this result also shows the still high dependence of the poor on the formal sector and the lack of ability to be independent and strive in the nonformal sectors.

In line with these findings, according to Tambunan (2001) in Mubyarto (2014), unemployment can affect poverty levels in various ways, including: First, if households have liquidity constraints which means that current consumption is strongly influenced by current income, then the unemployment disaster will directly affect the poverty rate income with the consumption poverty rate. Second, if households do not face liquidity constraints which means that current consumption is not too affected by current income, then the increase in unemployment will lead to an increase in poverty in the long run, but not too much in the short term. This, among others, was examined by Cutler and Katz (1991) and Powers (1995) in Mubyarto (2014) who found a strong relationship between poverty levels and various macroeconomic variables. These studies also prove that the unemployment rate and inflation are both positively related to the number of people who are below the poverty line or in other words the higher the rate of inflation and unemployment, the greater the level of poverty.

\section{CONCLUSION}

1. Capital Expenditures have a positive and significant influence on the District / City Poverty Levels in Gorontalo Province in the 2010-2016 period.

2. Human Development Index has a positive and significant influence on the District / City Poverty Level in Gorontalo Province.

3. Unemployment has a positive but not significant impact on the District / City Poverty Level in Gorontalo Province.

\section{REFERENCES}
A.P, Andyka. 2015. Pengaruh Pendapatan Asli Daerah, Dana Alokasi Umum, Dana Bagi 
Hasil Dan Belanja Daerah Terhadap Tingkat Kemiskinan DKI Jakarta. Semarang. Dalam http://eprints.undip.ac.id/45455/1/02 _PRATOMO.pdf. Diakses 22 September 2017 jam 22.29 WITA.

Aisyah, Nyayu. 2004. Keterkaitan Antara Indikator Pembangunan Ekonomi dan Indeks Pembangunan Manusia dalam Perekonomian Indonesia Analisis Antar Wilayah. Bogor. Dalam https://media.neliti.com/media/public ations/115781.pdf. Diakses 31 Januari 2018 jam 11.47 WITA.

Al Jundi, Musa. 2014. Analisis Faktor Yang Mempengaruhi Tingkat Kemiskinan Provinsi-provinsi di Indonesia. Semarang. Dalam http://eprints.undip.ac.id/45391/1/05 _JUNDI.pdf. Diakses 22 September 2017 jam 21.35 WITA.

Arham,Muh. Amir, Naue, Tresya F. 2015. Public expenditures and poverty: evaluation of the government's priority programs in Gorontalo Province. Economic Journal of Emerging Markets, Volume 7, No.2. Hal. 107-119.

Badan Pusat Statistika. 2015 Jumlah Penduduk Miskin (Ribu) dan Persentase Penduduk Miskin (\%) Menurut Kabupaten/Kota di Provinsi Gorontalo, 2004-2015. BPS.

Dahmardeh Nazar, Tabar Mahmoud Hasemi. 2013. Government Expenditures and its Impact on Poverty Reduction (Empirical From Sistan and Baluchestan Province of Iran). International Journal of Academic Research in Economics and Management Sciences, Volume 2, No.1.Hal. 251-260.
Kaplale, Raihana. 2012. Faktor- faktor Mempengaruhi Tingkat Kemiskinan di Kota Ambon. Jurnal Agribisnis Kepulauan, Volume 1, No.1.Hal. 101-115.

Kotambunan, Lavenia, Sutomo Wim Palar dan Richard L.H Tumikar. 2016. Analisis Pengaruh Belanja Modal dan Indeks Pembangunan Manusia (IPM) terhadap Kemiskinan di Provinsi Sulawesi Utara (Dalam Tahun 20052014).Jurnal Berkala Ilmiah Efisiensi, Volume 16, No. 1. Hal. 925-933.

Laiya, S.W. 2017. Pengaruh Pengangguran dan Indeks Pembangunan Manusia terhadap Kemiskinan di Kota Gorontalo Periode 2010-2015. Gorontalo.

Mirza, Denni Sulistio. 2012. Pengaruh Kemiskinan, Pertumbuhan Ekonomi, dan Belanja Modal terhadap Indeks Pembangunan Manusia di Jawa Tengah Tahun 20062009. Economics Development Analysis Journal. Volume 1, No. 1. Hal. 1-15.

Mubyarto, Novi. 2014. Pengaruh Pertumbuhan Ekonomi Dan Perubahan Ketimpangan Pendapatan Terhadap Kemiskinan Di Sumatera (The Influence Of Economic Growth And Change In Income Inequality On Poverty In Sumatra). Bandung. Dalam http://163.53.187.178/jurnal/index.php /JD/article/download/20/20.pdf.

Diakses 31 Januari 2018 jam 11.47 WITA.

Omari Loyce V. dan Willy Muturi. 2016. The Effect of Government Sectoral Expenditure on Poverty Level in Kenya. Global Journal of HUMAN- 
SOCIAL SCIENCE: Economics. Volume 16 Issue 2. Hal. 1-10.

S.Hasan,Yusrin. 2017. Pengaruh Alokasi Dana Desa Terhadap Ketimpangan Distribusi Pendapatan di Indonesia. Gorontalo.

Sudarlan. 2015. Contribution Of Human Development Index On Per Capita Income Growth And Poverty

Alleviation In Indonesia.

International Journal Of Scientific \& Technology Research. Volume 4, Issue 08. Hal. 173-178.

R, Rusmarinda. (2016). Pengaruh Indeks Pembangunan Manusia (IPM)< Tenaga Kerja (TK) dan Pendidikan Terhadap Pertumbuhan Ekonomi di Provinsi Jawa Tengah. Surakarta. Dalam http://eprints.ums.ac.id/418 10/1/NASKAH\%20PUBLIK

ASI.pdf. Download 21 September 2017 jam 20.41 WITA.

Setiyawati, Anis. dan Hamzah, Ardi. (2007) Analisis Pengaruh PAD, DAU, DAK Dan Belanja Pembangunan Terhadap Pertumbuhan Ekonomi, Kemiskinan, Dan Pengangguran. Jurnal Akuntansi dan Keuangan Indonesia, Volume 4, No.2. Hal. 211288.

Sukmaraga, Prima. (2011). Analisis Pengaruh Indeks Pembangunan Manusia, PDRB Perkapita, Jumlah Pengangguran Terhadap Jumlah Penduduk Miskin di Provinsi Jawa Tengah. Semarang. Dalam http://eprints.undip.ac.id/26773/1/skr ipsi_full.pdf. Download 23 September 2017 jam 11.33 WITA.
Suliswanto, Muhammad Sri Wahyudi. (2010). Pengaruh Produk Domestik Bruto (PDB) dan Indeks Pembangunan Manusia (IPM) terhadap Angka Kemiskinan di Indonesia. Jurnal Ekonomi Pembangunan, Volume 8, No.2. Hal. 357-366.

Yacoub, Yarlina. (2012). Pengaruh Tingkat Pengangguran terhadap Tingkat Kemiskinan Kabupaten/Kota di Provinsi Kalimantan Barat. Jurnal Eksos, Volume 8, No.3. Hal. 176185. 